\title{
Lumen
}

Selected Proceedings from the Canadian Society for Eighteenth-Century Studies

\section{The Poetical Trade of Favours: Swift, Mary Barber, and the Counterfeit Letters}

\section{Wendy Stewart}

Volume 18, 1999

Representations of Time in the XVIIIth Century

Le temps et ses représentations au dix-huitième siècle

URI : https://id.erudit.org/iderudit/1012373ar

DOI : https://doi.org/10.7202/1012373ar

Aller au sommaire du numéro

Éditeur(s)

Canadian Society for Eighteenth-Century Studies / Société canadienne d'étude du dix-huitième siècle

ISSN

1209-3696 (imprimé)

1927-8284 (numérique)

Découvrir la revue

Citer cet article

Stewart, W. (1999). The Poetical Trade of Favours: Swift, Mary Barber, and the Counterfeit Letters. Lumen, 18, 155-174. https://doi.org/10.7202/1012373ar

Copyright (c) Canadian Society for Eighteenth-Century Studies / Sociéte canadienne d'étude du dix-huitième siècle, 1999
Ce document est protégé par la loi sur le droit d'auteur. L'utilisation des services d'Érudit (y compris la reproduction) est assujettie à sa politique d'utilisation que vous pouvez consulter en ligne.

https://apropos.erudit.org/fr/usagers/politique-dutilisation/ 


\section{The Poetical Trade of Favours: Swift, Mary Barber, and the Counterfeit Letters}

In a letter dated 22 June 1731 and signed 'your Majesty's most dutifull $\&$ loyal subject and serv ${ }^{t} J o n a t h$. Swift', the writer complains to Queen Caroline about the neglected state of Ireland, 'removed from the Prince's eye, and of consequence from the influence both of his wisdom and goodness', and cites as an example of English indifference the failure of the poet Mary Barber to secure royal patronage:

to omit a thous ${ }^{\mathrm{d}}$ other instances, there is one person of Irish birth, eminent for genius, and merit of many kinds, an honour to her Country, and to her Sex; I will be bold to say, not less so in her Sphere, than your Majesty in yours; and yet all talents and vertues have not yet been able to influence any one person about $y^{r}$ Majesty, so far as to introduce her into $\mathrm{y}^{\mathrm{r}}$ least notice: as I am $\mathrm{y}^{\mathrm{r}}$ Majesty's most dutifull and Loyal Subject, tis a debt I owe your Majesty to acquaint you, that $\mathrm{M}^{\mathrm{rs}}$ Barber, the best female poet of this or perhaps of any age, is now in your Majesty's capital; known to Lady Harford, Lady Torrington, Lady Walpole \&c. a woman whose genius is honoured by every man of genius in this Kingdom, and either honoured or envy'd by every man of genius in England.

After this high praise, Caroline's patronage is asked in an appeal which curiously combines rebuke and flattery:

Your Majesty is justly reverenced for those great abilities with $w^{\text {ch }}$ God hath blesst you; for $y^{r}$ regard to learning, and $y^{r}$ zeal for true religion. Compleat your character by your regard to persons of genius; especially those, who make the greatness of their talents, after your Majesty's example, subservient to the good of mankind, and the glory of god, which is most remarkably $\mathrm{M}^{\mathrm{rs}}$ Barber's case and character. ${ }^{1}$

On 20 July, Swift wrote to Pope denying any involvement in the ' 3 lettrs [...] supposed all to be writt by me to the Qu - on Mrs B's account' (3:479). The other two letters have been lost; only the letter bearing his signature was 'returned' to Swift by Pope. ${ }^{2}$ Naturally I am intrigued by 
the question of who made such a bold claim - and such an inappropriate address to a monarch, in an age in which most literary works, including Barber's own Poems on Several Occasions dated 1734, are prefaced with protestations of humility - on the poet's behalf. Clearly Swift, Mary Barber's chief patron and mentor, was embarrassed by the incident and minimizes his involvement in her subscription campaign in his letter to Pope:

to write to the $\mathrm{Qu}$ - who hath used me ill without any cause, and to write in such a manner as the lett you sent me, and in such a Style, and to have so much zeal for one almost a Stranger, and to make such a description of a woman as to prefer her before all man kind, and to instance it as one of the greatest grievances of Ireld, that Her M - hath not encouraged $\mathrm{M}^{\mathrm{rs}} \mathrm{B}$ - a woollen-drapers wife, declind in the world, because she hath a knack of versifying, was to suppose or fear a folly so transcendent that no man could be guilty of who was not fit for Bedlam. (3:479)

Swift quickly either forgave or exculpated Barber, but the authorship of these letters has never been resolved. Roger Lonsdale attributes it to Barber 'or a clumsy well-wisher', but as Irvin Ehrenpreis points out, '[it] is hard to believe that anyone who hoped simply to aid Mrs Barber or to trouble Swift would have concocted so transparent a bluff. ${ }^{3}$ Despite Swift's ascription to her of 'every kind virtue, and only one defect, which is too much bashfullness', ${ }^{4}$ Barber remains the most likely suspect, at least for the letter bearing Swift's forged signature.

Certainly I cannot claim to be sure of the letters' authorship. However, the manner in which the favour of royal patronage is asked is at least as important as the author's identity. The letter and its attribution to Swift focus attention on the trade in favours implicit in the system of publication by subscription, a form of literary patronage which had begun early in the seventeenth century but was becoming prevalent only during the eighteenth. The practice is defined as follows:

The word "subscription" itself [...] signifies an agreement between an author or a bookseller on the one hand and a number of individuals on the other; the author or bookseller agrees to produce a book of specified content, size, and quality, whose publication is financed by the individuals, or subscribers, each of whom receives in return a copy or copies of the book. ${ }^{5}$

Institutionally, subscription functioned as 'a half-way house between dependance on a single patron to underwrite a book and reliance upon sales. ${ }^{6}$ Changes in the institutions of publishing necessarily meant changes to the relationships among all the parties involved: writer, 
patron or mentor, bookseller, and reader/subscriber. Dustin Griffin writes that as the century progressed, 'booksellers gained both economic power and cultural authority, but did not supplant the traditional patrons: the period is characterized by overlapping "economies" of patronage and marketplace. ${ }^{7}$

Correspondent changes in power relationships during this period foregrounded the relation between writer and reader. Traditional literary patronage had excluded all but a few female writers from publication. However, as Griffin observes:

Women in fact participated in the patronage system, both as patrons and authors, from the beginning of the century, and (especially if subscription publication is considered) benefited from patronage in increasing numbers as the century ended. [...] Indeed, it appears that the system of subscription publication made it more likely that a woman writer's poems would see print. Had women had to depend solely on copy money from booksellers, far fewer would have entered the ranks of published authors. (189-90)

Mary Barber, the subject and perhaps the author of the letter seeking Caroline's patronage, was one such female writer. Her subscription campaign was very successful; more than 900 people subscribed to Poems on Several Occasions, several for multiple copies. To put this number into perspective, Alexander Pope's 1715 translation of the Iliad garnered 653 subscriptions; his Odyssey, published in 1725, sold 847 copies in advance of publication. ${ }^{8}$ Both of these works were enormously popular and the number of subscriptions was high, considering that they were expensive editions. But Barber's volume of poems and her subscription campaign are more instructively compared with those of another female poet. Some ten to fifteen years later, Mary Jones and her patron Lady Bowyer would secure the Princess Royal's subscription for Jones's collection of poetry; with this advantage, Jones amassed more than 1,400 subscribers for her 1750 Miscellanies in Prose and Verse. The advantage of inscribing a royal title on one's subscription list is obvious, and there can be no doubt that Mary Barber wanted Caroline's patronage.

The counterfeit letter, whether written by Barber or someone else, demonstrates a crucial problem faced by discrete groups of writers but especially by women publishing for remuneration: how to advance oneself without endangering one's reputation and thereby one's potential subscriptions. I want to suggest that the appropriation of Swift's signature signifies Barber's misreading and misapplication of what Pierre Bourdieu refers to as the 'capital of consecration.' This symbolic capital has 'a power to consecrate objects (with a trademark or signature) or persons (through publication, exhibition, etc.) and therefore to give 
value, and to appropriate the profits from this operation. ${ }^{10}$ In other words, in writing the letter Barber appropriates Swift's symbolic capital of consecration in order literally to do herself a favour. This paper will examine the appearance of the counterfeit letter as an unsuccessful attempt by Barber to use the favour as cultural currency.

\section{Virtuous Modest Gentlewoman; or, How She Succeeded in Her Subscription}

Mary Barber, c. 1685-1755, was an Anglo-Irish poet who along with her peers Constantia Grierson and Mrs. Sican made up what Jonathan Swift called his "Triumfeminate. ${ }^{11}$ She was good at claiming favours. The wife of a not particularly successful Dublin merchant, ${ }^{12}$ Barber managed to place one of her sons under the care of John Barber (to whom she was not related), Lord Mayor of London. In 1736, when her health was failing, she successfully asked Swift for the English publication rights to his Polite Conversations to help support her family. Most important, she was successful in amassing subscriptions to her volume of poetry. Many of the subscribers to the quarto edition of Poems on Several Occasions dated $1734^{13}$ were impressed by qualities described by her chief mentor and patron, Jonathan Swift, to a potential subscriber: 'I believe few persons have met with more considerable friends and Patrons than She; and very well diserves their favor, by her Virtue, her humility, Gratitude and Poetical Genius. ${ }^{14}$

The order in which these qualities are listed is important in analyzing the reasons for Barber's success in a system of publication and remuneration in which the perceived favour of the patron - here the subscriber - counts for at least as much as his or her payment, because one subscriber had the power to recommend others. For example, in 1731, at which time Barber's subscription campaign was well underway, Pope wrote to Swift that while he would not correct Mary Barber's verses, as she had asked:

Whatever Service I can render her, by speaking well \&c. I will. Whatever Friends I can get to Subscribe to her, I will. [...] All your Friends She will have without me; and all their Friends. But I'll do all I can. I must in return press you to speak well (as You justly may) of an Abridgment of the Roman History, a Subscription for which is going in Ireland [...]. ${ }^{15}$

This letter highlights the trade of favours involved in publication by subscription: exchanging favours on behalf of their protégés confirmed to themselves and to each other Swift's and Pope's own status as patrons 
and mentors of lesser writers. Subscription undoubtedly proved for some writers a 'democratization [of] literary patronage' which diminished the client's 'sense of obligation' to the traditional patron or patrons. ${ }^{16}$ For others, however, especially women, subscription could simply mean more patrons to satisfy. Swift's enumeration of Barber's merits - in the legitimate letter - attempts to address this problem.

First, and most important to Swift and to Mary Barber's subscribers, is her virtue. Barber was writing to support her family, although this was of course only rarely made explicit during the four years leading up to the publication of Poems on Several Occasions in which she travelled in England and Ireland gathering subscriptions. Correspondence of Swift's circle sheds light on Rupert Barber's failure to provide for his family. On 7 September 1731, Lady Elizabeth Germain wrote Swift:

I saw $\mathrm{M}^{\text {rs }}$ Barber the day before I came out of town and shoud be mighty glad to serve her, but I cant say so much by her husband whom for her sake I recommended to the Duke of Dorset to buy his Liverys on, the first thing he did was to ask a greater price than any body else and when we were at Whitchurch where I attended their Graces, he was informed he had Cloth near enough in his shop and they feared they would not be ready against he came over [...].

By the early 1730s, Mary Barber appears to have been on her own. In fact so little is heard of Rupert Barber that some biographers assumed that he was dead by $1733 .{ }^{17}$ From at least 1730 , Mary Barber suffered poor health (letters refer to her disabling attacks of gout or arthritis, asthma, and other complaints); Barber's great patrons Patrick and Mary Delany feared that her death would leave her children - whom Patrick Delany described as 'excellently educated, perfectly well-disposed, and utterly unprovided for' - destitute. As late as 1747, Mary Delany lamented that the Barbers' only daughter, Myra or Mira (b. 1717), 'who [was] in a deplorable way', and youngest son, Lucius (b. 1720), 'were entirely maintained by her and Betty Woddal, who had the care of Myra.' In 1755 Mary Delany wrote: 'Old Mr. Barber is alive, drinks his claret, smokes his pipe, and cares not a pin for any of his family, who, if they had not met with better friends than himself, might have starved! ${ }^{18}$ Granted, this last and most often quoted judgment of Rupert Barber was made after the two surviving elder sons, Constantine (b. 1714) and Rupert Jr. (b. 1719), were established in successful careers as, respectively, a physician and a painter of miniatures. That Mary Barber, despite her poor health which, along with good humour, Swift deemed 'absolutely necessary in the poetical trade ${ }^{19}$ - was since at least the early 1730 s the primary provider is demonstrated by the efforts of Swift, the Delanys, and many of their circle over three decades to find support for Mary Barber and her 
children. Indeed, it is important to consider contemporary attitudes toward charity as well as remunerated work when examining the subscription campaigns of Barber and others.

The poet does not emphasize the urgency of her family's need for a successful subscription but rather left this to her subscribers when they referred her to their friends and acquaintances for subscriptions. For Mary Barber to have made such an admission would have been disloyal to her husband, and her reticence about her husband's shortcomings was in itself an indication of her virtue. The poet needed to convince her patrons, here her subscribers, of the acceptability of her character as well as of her poetic subjects in order to sell her product. A letter from one felicitously named Mrs. Conduitt to Swift dated 29 November 1733 says as much: '[Mrs. Barber] has as much a better title to the favour of her sex than poetry can give her, as truth is better than fiction; and shall have my best assistance' (4:213-14). The Conduitts, like many of Barber's subscribers, endorsed the woman by supporting the poet.

The second quality Swift singles out, difficult to reconcile with the claims made in the counterfeit letter, is the poet's humility. Mary Barber begins the preface to Poems on Several Occasions with the acknowledgement that 'a Woman steps out of her Province, whenever she presumes to write for the Press', ${ }^{20}$ and ends the last poem of the volume, '[T] o Lady, who commanded me to send her an Account in Verse, how I succeeded in my Subscription' (282-90), with the somewhat disingenuous disclaimer:

One Merit I presume to boast,

And dare to plead but one at most:

The Muse I never have debas' $\mathrm{d}$;

My Lays are innocent at least;

Were ever ardently design'd

To mend and to enlarge the Mind.

This must be own'd a virtuous Aim.

The Praise of Wit — let others claim. (127-34)

Barber makes it clear that her literary activity is conducted for laudable and gender-appropriate purposes, authorized, as it was, by maternal, didactic, and charitable motives. ${ }^{21}$

As to her gratitude, the third quality Swift lists, despite the contradictions in Mary Barber's character that such incidents as the counterfeit letter might bring to light, there is sufficient evidence of her 'sincere, but overflowing Spirit of Thankfulness' ${ }^{22}$ in her poems, her letters, and others' letters about her to assume that she was genuinely appreciative of the help she received polishing and publishing her poems. Twentieth- 
century readers of Barber's poems have tended to share Ehrenpreis's judgment that 'she wrote with more attention to patrons than to readers' (3:636). However, in his letter to Lord Orrery, to whom Poems on Several Occasions is dedicated, Swift seems to anticipate such criticism and defends the real merit of her poetry and of her character: '[a]ltho' the World in general may possibly continue in its usual Sentiments, and list her in the common Herd of Dedicators. ${ }^{23}$ Indeed, one of the few comments on the critical reception of Poems on Several Occasions indicates that the poet may not have flattered as much as might have been expected: 'her poems are generally greatly liked: there are, indeed, a few severe critics (who think that judgment is only shewn in finding faults) that say they are not poetic; and a few fine ladies, who are not commended in them, that complain they are dull. ${ }^{24}$ Mary Barber seems to have adopted the correct attitude of a minor writer, especially one publishing by subscription; dismissing her poetry because it demonstrates the circumstances of its production seems not only unfair but short-sighted.

As for Swift's assertion of her poetical genius, although Barber's work could not have been considered great poetry by very many standards, it is true poetry rather than mere versifying. The fact that it is Mary Barber's own experience, own hopes, own philosophy, and own fantasies rendered into competent, usually consciously unheroic form and voice virtually precludes it from being considered great poetry; the subject matter is all wrong for canonical greatness, as are the sex and class of the poet. However, readers would recognize true wit as that which reflects their own experience, etc.; Barber's poetry would represent, to many contemporary readers, 'Is]omething, whose Truth convinc'd at Sight we find, / That gives us back the Image of our Mind.' Barber's conceits are homely, her sentiments usually sincere and well-meant: that one must care for one's children, help one's friends, get used to the facts of aging and death, deal ethically with others, and be very careful in one's choice of marriage partner - subjects difficult to quarrel with, but perhaps also difficult to make compelling poetry of. Yet she did, and it sold - by subscription.

In short, Mary Barber did compel favours in the form of patronage and subscription quite successfully. Swift's patronage and mentorship was crucial to her subscription campaign, but Barber frequently appealed personally to potential subscribers, often with letters of introduction and recommendation from Swift and from other patrons and subscribers - that is, with letters very much like the one quoted from Swift, praising her qualities, and ultimately, except in tone, not so different from the counterfeit letter. Why, then, did the counterfeit letter requesting royal patronage fail so abysmally? Why did this event occur at all? 


\section{Strange, Bold, and Disagreeable Assertions}

To write such a letter, in which Barber claims to be the envy or honour of every man of genius in England and the equal in her own sphere of Caroline in hers, is, to say the least, overreaching. No wonder Barber was called 'strange, bold, and disagreeable' by Lady Russell in a letter to Charlotte Clayton; the letter is all those things and would be so regardless of who had written it. ${ }^{25}$ In his letter to Pope quoted above, one of the claims Swift singles out as particularly offensive is that the writer would 'make such a description of a woman as to prefer her before all man kind, in pronouncing this female poet either honoured or envy'd by every man of genius in England.' Swift notes that the letter is written in an unfamiliar hand, but proof even more conclusive, in his eyes, that the letter is a forgery is its closing compliment: '[y]ou will observe the lett ${ }^{r}$ you sent me, concluded Your Majesty's loyall Subject, $\mathrm{w}^{\text {ch }}$ is absolutely absurd, for we are onely Subjects to the K; and so is $\mathrm{He}^{\mathrm{r}} \mathrm{M}$ - her self' (3:480). No woman, least of all 'a woollen-drapers wife, declind in the world', takes pride of place.

The letter is overreaching in another, very literal sense: Barber fails to comprehend the limits of the contemporary patronage paradigm as it is outlined by Betty Rizzo. ${ }^{26}$ Stephen Duck 'the Thresher Poet' secured Caroline's patronage (during the same years that Barber was seeking it), setting, as Rizzo discovers, rather than following a pattern for the relationship between patron and 'natural' (i.e., unschooled and labouring-class) poet of the eighteenth century. In this pattern, the poet is discovered by a local patron or group of patrons and is transferred upwards even unto the court. I suggest that Barber may have seen in Duck's career a trajectory for her own, and that, having been handed up from her discoverer, the poet Thomas Tickell (to whom, incidentally, she had anonymously sent the first of her poems to be published, in 1724) to the Carterets and Delanys to Swift, to Lord Orrery, the dedicatee of Poems on Several Occasions, and finally on to the growing list of subscribers, Barber expected or at least hoped to secure royal patronage.

It is impossible to know what might have happened, had the unfortunate letter not arrived at its destination, but I suspect that Barber's hopes for royal patronage would have gone unrewarded. As Rizzo makes plain, royal patronage of the natural poet had distinct political advantages for the patron as well as for the poet. Barber simply did not fit the mould of the natural poet: she had some (probably informal) education, fairly extensive contacts with her social betters even before she began writing for publication, and a keen and often passionately expressed sense of the injustices of extant class, gender, and national relations. As might be expected of an Irish poet and associate of Swift's, 
some of her poems explicitly criticize the workings of Empire. Barber wrote against slavery some fifty years before it became fashionable to do so, in '[O]n seeing the Captives, lately redeem'd from Barbary by His Majesty' (278-81). She censured the mode if not the fact of British rule of Ireland in several poems, including 'An Invitation to Edward Walpole, Esq; upon hearing he was landed in Dublin' (203-4), even while securing Sir Robert's subscription for five copies and his son Edward's for one. And her 'petition poems' - most of which solicit patronage on behalf of distressed gentlewomen, and the first of which started her public career - point out the injustice of the military / class system. In fact, one such poem, 'On seeing an Officer's Widow distracted who had been driven to Despair, by a long and fruitless Sollicitation for the Arrears of her Pension' (240-42), could more accurately be said to anticipate Blake than to imitate Swift.

In addition to criticizing larger social and institutional iniquities, Mary Barber took a sharp look at the very system that enabled her publication. While a few of her poetic addresses to patrons are undeniably obsequious, it is more fair to say that patronage, as both fact of publication and as subject matter, was germane to her poetry. As the last poem of the volume demonstrates, Barber was no lickspittle. The aforementioned 'To a Lady, who commanded me to send her an Account in Verse, how I succeeded in my Subscription' satirically rehearses potential subscribers' reasons for withholding their patronage. One is that she is a woman writing at all:

SERVILla cries, I hate a wit;

Women should to their Fate submit,

Should in the Needle take Delight;

'Tis out of Character to write. (11-14)

In fact, says Fulvia, not only should women not write, they cannot:

I oft have said, and say again,

Verses are only writ by Men;

I know a Woman cannot write;

I do not say this out of Spite;

Nor shall be thought, by those who know me,

To envy one so much below me. (33-38)

In putting her character abroad, as is necessary in subscription, the female poet risks exposing it to malicious reflection. The familiar equation of women's publication with sexual promiscuity is made in this gossipy condemnation of the poet's popularity: 
She may succeed among the Men;

They tell me, SwIFT subscribes for Ten:

And some say, Dorset does the same;

But she shall never have my Name. (15-18)

Barber deflates real criticism of her poetry by having these fictionalized 'critics' - few of whom have actually read her poems - reveal the self-interest informing their criticism. One complains that the poet does not flatter her subscribers enough:

Thus SILVIA, of the haughty Tribe:

She never ask'd me to subscribe,

Nor ever wrote a Line on me,

I was no Theme for Poetry!

She rightly judg'd; I have no Taste -

For Womens Poetry, at least. (25-30)

Another finds fault with Barber's didactic poetry:

SABINA, fam'd in Wisdom's School, Allows I write - but am a Fool:

"What! - must our Sons be form'd by Rhyme?

"A fine Way to employ one's Time!" (39-42)

Pulvilio, one of only two male critics in the poem, judges that, although he has not read Barber's poetry - supporting subscriptions for literary works 'looks like Pedantry' (72) - it cannot be worth reading because the poet is too conventional:

She talks just in the common Way:

Sure Wits their Talents should display;

Their Language surely should be bright,

Before they should pretend to write. (68-70)

Belinda, on the other hand, approves only one of the most conventional poems in the collection:

Stella and Flavia's well enough;

What else I saw, was stupid Stuff;

Nor Love nor Satire in her Lays,

Insipid! neither pain nor please. (81-84) 
Each of these complaints Barber shows to be the result of some character defect of the aristocratic complainer rather than a judicious comment on her work. By having the critics' implied demands contradict one another, the poem demonstrates the impossibility of pleasing everyone who thinks they should be pleased by the poetry of a woman of Barber's time and station. So, whereas the 'natural poets', to quote Rizzo, 'made splendid household pets who could fawn in words' $(242)$, Barber could not be counted on to tell anyone what they wanted to hear (as the counterfeit letter makes clear!), and could not have been expected to play the part of a properly grateful royal protégée.

\section{Not Less So in Her Sphere, Than Your Majesty in Yours}

Another problem the counterfeit letter demonstrates is that in attempting to justify royal patronage by identifying herself with the Queen, as the equal in her own sphere of Caroline in hers, Barber was trying to board a ship that had long since sailed. Carol Barash demonstrates that women's poetry had flourished under Queen Anne (r. 1702-14) in part because women could authorize their act of writing for publication by pointing to the very public authority of the Queen. ${ }^{27}$ 'In writings by women in the early years of Anne's reign, the making of a specifically English literary tradition and the legitimation of women's writing are consistently linked. Under a female ruler [...] women writers have a central place in the formation of a coherent national language and literature' (232). Barash points out that this relationship between female writer and female monarch was not typical; in fact, Anne was perhaps anomalous in inspiring such a hopeful redefinition of the position of the female writer. She cites the example of Catharine Trotter Cockburn, poet and playwright who wrote during both Anne's and Caroline's reigns. Under Anne's patronage, Cockburn had seen herself as 'competing with male dramatists and authorized by the queen to continue in such warfare' (254), a competition that calls to mind the one in the counterfeit letter, in which Barber boasts that she is honoured or envied by every man of genius in England and Ireland. However, when Cockburn came to write a poem for Caroline, 'she emphasized her distance from the queen. [...] Instead of a public battle for linguistic authority, she retreated behind a veil of virtue. Cockburn participated in the larger construction of passive womanhood, an ideal which she herself violated in the very act of publishing writings in its favour' (258). My point is that Caroline, influential though she was, was the Queen Consort and not the Queen Regnant; to paraphrase Swift's indignant response to the counterfeit letters, even Caroline was only a subject. Barber misread both Caroline's 
authority and the female poet's access to authorization by it. The misinformed attempt to gain royal authorization fails in part because Barber is of the wrong class - the female writers who found authorization in Anne's reign had almost all been of the court circle - but it fails because Caroline is also of the wrong category.

No longer did the female monarch authorize women's public writing; in fact Caroline seems to have been, if such a thing is possible, actively negligent. Unlike her husband, Caroline was very interested in theology, philosophy, the sciences, history, and old plays in French and English.

Indeed, she was "curious in everything", $[\ldots]$ and "read and conversed" on more subjects than the average man, with a breadth of outlook and sureness of judgment that were exceedingly masculine, though her erudition was so lightly carried it never grew tedious. ${ }^{28}$

However, Caroline did not appear to have been especially interested in poetry, at least not to the degree that Anne had been. Or rather when she did show interest in poets, as in the case of Stephen Duck, whose poetry tended necessarily to panegyric, it was for political ends. In fact, in 1730, the year in which Barber was just beginning to gather patrons of her own, Duck was being seriously considered for the laureateship eventually bestowed upon Colley Cibber. ${ }^{29}$ In contrast to Pope's treatment of the affair in The Dunciad, Barber's attitude toward both Duck and Caroline seems characteristically generous and optimistic. Near the end of a poem extremely critical of England's oppressive treatment of Ireland, Barber expresses the belief that since Caroline had recognized and rewarded Duck's merit, there may yet be hope for both her country and for poetry:

YET sometimes we in Story find

An Instance of a noble Mind,

That made Apolto's Shrine its Care,

And bless'd the Tribe that worshipp'd there.

[...]

Euza paid her Spencer's Toil

With Acres of Hibernian Soil:

And now illustrious CAROLINE

Resolves to raise the drooping Nine;

With Pleasure saw the lab'ring Hind

Studious to cultivate his Mind;

And deign'd to smile on rural Lines,

Where so much native Beauty shines. ${ }^{30}$ 


\section{Who Thus Instructs the Royal Race, Must Have a Pension, or a Place}

'A True Tale' (7-12) is one of Barber's petition poems, this one on behalf of John Gay rather than the more typical subject, a distressed gentlewoman. In it, Barber describes the situation of the better-known writer who, despite having 'found the Art, / To raise the Mind, and mend the Heart' (47-48) (motives Barber consistently uses to justify publishing her own poetry) is denied royal patronage. The speaker's young son reads Gay's Fables, is appropriately edified, then weeps upon learning that Gay has not been rewarded with Caroline's patronage. His mother reassures the boy:

He should hope the best:

This has been yet Gay's Case, I own,

But now his Merit's amply known.

Content that tender Heart of thine:

He'll be the Care of Caroline.

Who thus instructs the royal Race,

Must have a Pension, or a Place. (71-72)

The child then asks his mother to imagine herself as Caroline, able to bestow patronage. This fantasy authorized by another ('Mamma, if you were Queen, says he' [73]) recalls the one in the counterfeit letter in which Barber, whom Swift would later describe as a 'virtuous modest Gentlewoman, with a great deal of good sense', ${ }^{31}$ becomes the equal, in her sphere, of Caroline in hers. In the poem, however, the speaker's reply indicates that even in fantasy she is unable to assume such a role:

Poets who write to mend the Mind,

A royal Recompence should find.

But I am barr'd by Fortune's Frowns,

From the best Privilege of CROWNS;

The glorious, god-like Pow'r to bless,

And raise up Merit in Distress. (79-84)

Barber is barred from the best privilege of crowns in the sense that she has no money to bestow upon Gay or any of the subjects of her petition poems. Another bar to the privilege of crowns is that Caroline's patronage, so clumsily requested in the counterfeit letter, is not forthcoming. When the child again insists his mother imagine herself Queen, the speaker briefly capitulates and replies that, were she Caroline, she would reward such a poet with 'At least, a thousand Pounds a Year' (88). 
Barber's petition poem on Gay's behalf reminds us that Gay had himself been largely unsuccessful in securing royal patronage. 1728 saw the production of his very popular Beggar's Opera, in which Caroline's favourite, Walpole, was caricatured in the highwayman Macheath. Walpole objected and forbade the sequel Polly to be performed. Despite Walpole's interdiction, Gay's patroness, the Duchess of Queensberry, collected subscriptions for Polly's publication. Banned from court by order of the King, she replied to her sentence with a note: 'The Duchess of Queensberry is surprised and well pleased that the King hath given her so agreeable a command as to stay from Court, where she never came for diversion, but to bestow a civility on the King and Queen [...].'32 Having failed to do a favour for Gay, the Duchess attempts to save face by pretending that the court was unable to recognize her favour to it. That Mary Barber should try to do Gay a similar favour when her superior had failed is both audacious and indicative of her loyalty to Swift and his friends. The poem was first published in 1728; Barber could easily have chosen not to include 'A True Tale' in Poems on Several Occasions. That she published it with the full knowledge of the court's displeasure with Gay demonstrates her wish to be identified, morally at least, with the Scriblerians. Gay, incidentally, makes light of Barber's intended favour. In April 1731, after boasting that he is, for the first time in a long time, 'as to fortune [...] an independant creature', he tells Swift: 'I made a visit to $\mathrm{M}^{\text {rs }}$ Barber, I wish I could any ways have contributed to her subscription; I have always found myself of no consequence \& am now of less than ever; but I have found out a way in one respect, of making myself of more consequence, which is by considering other people of less. ${ }^{.33}$

\section{'I'm Glad the Medals Were Forgot': Swift and Caroline}

Since Barber was unsuitable for royal patronage, even a legitimate request by Swift on her behalf may have failed to gain her much advantage. However by 1731, the year the counterfeit letters appear, Swift simply no longer had the influence necessary to secure Caroline's favour for his protégée. Rizzo describes the coolness between Pope and Caroline at the time, due in part to Caroline's preference of Stephen Duck, that 'household pet', and to Pope's satire of the court of George II in The Dunciad of 1728 (Rizzo 244-48). Swift, in part because of his friendship and collaborations with Pope, would not have been a likely candidate for Caroline's patronage. But by this time, Swift and Caroline had had a falling-out of their own; Swift alludes to this event in the letter to Pope in which he denies authorship of the counterfeit letter. In 1726, Swift had 
sent some Irish poplin to the then-Princess Caroline. Dustin Griffin argues that Swift wanted to be seen as doing a favour for Caroline and was disappointed when she failed to reciprocate with some medals she had promised in exchange. ${ }^{34}$ Bourdieu's analysis of the proper exchange and function of gifts is helpful in analyzing this failed exchange of favours. In order to maintain a friendship, that is, a relationship based on mutual debt between people who are at least potentially equals, the returned gift cannot be in kind (a swap), for such a rejection of indebtedness insults the giver. The exchanged thing cannot be money, because that would reduce the gift exchange to a financial transaction and would, like the swap, negate reciprocal indebtedness and thus friendship: '[If] it is not to constitute an insult, the counter-gift must be deferred and different. ${ }^{35}$ The promised medals, then, bestowed after her ascension to the throne would have been an ideal gift, implying Caroline's recognition of Swift's favour to her and friendship with her.

However, Swift interpreted Caroline's reneging on her promise to give him the medals as, in Griffin's words, 'not royal largesse promised and withdrawn, not an Irish merchant providing goods to the carriage trade, but (somewhat cheekily) an exchange of gifts between equals that one party has failed to fulfill. ${ }^{36}$ In 1729 , he complained to Pope that 'Mrs. Howard, and her Mistress [...] have neither memory nor manners; else I should have some mark of the former from the latter, which I was promised above two years ago; but, since I made them a present, it would be mean to remind them. ${ }^{37}$ Two years later, 'Verses on the Death of Dr. Swift, D.S.P.D.' tells something of Swift's attitude toward the affair:

Kind Lady Suffolk in the spleen, Runs laughing up to tell the Queen.

The Queen, so gracious, mild, and good, Cries, - 'Is he gone? 'Tis time he should.

He's dead, you say, why let him rot;

I'm glad the medals were forgot.

I promised him, I own; but when?

I only was the Princess then;

But now as consort of the King,

You know 'tis quite a different thing. ${ }^{38}$

Caroline had rebuffed his familiarity, his suggestion that they were, on any level, something like equals although before her coronation she had been friendly and even encouraging to Swift. Perhaps this would make Barber's claim in the counterfeit letter that she is equal in her sphere of Caroline in hers especially offensive. 


\section{Conclusion}

In the end, Swift may be seen as having played an indirect and unwilling role in the affair of the counterfeit letter after all. His only surviving letter to Mary Barber is dated 23 February 1731, two years after the end of the incident that underscored his own failure with Caroline, four months before the counterfeit letters would appear. The business-like letter arranges details of the subscription campaign for Poems on Several Occasions, at that time already several months underway, lists potential collectors (subscribers who would collect the subscription guineas from other subscribers who might not otherwise remember to pay), and jocularly threatens to 'force them to obedience' - that is, to subscribe and to gather subscriptions for Barber. It ends with a postscript in which he advises, apparently seriously: 'let $\mathrm{M}^{\mathrm{rs}}$ Howard know that I recommend you to the Queen and wou'd apply to her in person if I were in England' (3:440). This direction implies that mere geographical distance is to blame for Swift's inability to put in a good word for his protégée to Caroline. In fact, nearly a year earlier Swift had told Pope that he would 'give her no letter of recommendation. ${ }^{39}$ Since he actually wrote Barber many letters of recommendation, I assume this means no letter of introduction to the court, and that Swift knew he had no claim on Caroline's favour. Did Barber take at face value Swift's assertion that, were he in England, he would recommend her to the Queen himself, and overestimate his influence? If so, and if she wrote the counterfeit letter, the strange, bold, and disagreeable letter may represent a gauche but understandable extrapolation of her mentor's stated intentions. Under these circumstances, the letter would constitute a fantasy of the type in 'A True Tale', in which power may be assumed without risk of censure because it is authorized by another.

The letter's attempt to press into service Swift's symbolic capital to secure Caroline's demonstrates that its writer understood the trickledown nature of the economy of subscription publication. I speculate, then, that Barber chose to accept Swift's portrayal of himself as a friend of Caroline's, and that as she had often legitimately and successfully traded on the power of one patron to secure another, she attempts, in the counterfeit letter, to do so again. Undoubtedly, Swift was responsible for the success of Barber's subscription campaign. His clerical position, literary reputation, and stature as an important social figure who knew many, if not most, of Barber's subscribers lent considerable prestige to the project of publishing Poems on Several Occasions. However, he himself lacked the consecration of the Queen's patronage, let alone her friendship, and so was unable to confer this extra degree of consecration sought by the counterfeit letter. Had Swift Caroline's favour, his patronage of 
Barber would have been worth more in terms of symbolic capital, and she might have gained by direct royal patronage as well as by the longer, more prestigious, and more lucrative subscription list Caroline's patronage would virtually ensure.

This inquiry into the affair of the counterfeit letter considers one (usually astute) writer's misreading of the various symbolic discourses of patronage, and her malpraxis of favour exchange as cultural practice. The affair should be seen in the larger context of a complex of negotiations that Mary Barber and other minor writers needed to make in order to publish their work. The appearance of the counterfeit letter at a time when the practice of publishing by subscription was still developing, its rules neither firmly established nor, probably, understood in precisely the same way by all parties involved, demonstrates that patronage, while changing in character, was hardly dying.

WENDY STEWART

McMaster University

\section{Notes}

1 Unless otherwise noted, all correspondence is from Harold Williams's edition of The Correspondence of Jonathan Swift, 5 vols (Oxford: Clarendon Press, 1963-65) 5:259-60 for this letter in full.

2 However, we know that only the letter of 22 June bore Swift's forged signature, and that one of the other letters was 'in abuse of Queen Caroline's friend, Mrs. Clayton, probably for concealing Mrs. Barber's merits from Her Majesty' (F. Elrington Ball's note, quoted in Williams, 3:479, n. 1). In a letter dated 5 June 1731, Lady Elizabeth Germain writes to Swift: 'I have not been in any way of seeing Mrs Barber this great while, but I hear \& I hope tis, that she goes on in her Subscription very well, nor has the Lady she so much feared done her any harm, if she endeavoured it, which is more than I know that she did' (3:470). Ball suggests that 'the allusion may be to a Mrs. Clayton, who was accused of attempting to obstruct Mrs. Barber in her canvass for subscribers' $(3: 470, n .1)$. This makes sense: Mrs. Clayton, later Viscountess Sundon, is the recipient of the letter later mentioned in this essay in which the writer refers to Mary Barber as 'strange, bold, and disagreeable.'

3 See Ehrenpreis, Swift: The Man, His Works, and the Age, 3 vols. (London: Methuen, 1962-1983) 3:703, and Lonsdale, Introduction to Barber, Eighteenth-Century Women Poets (Oxford: Oxford UP, 1990) 118. While A.C. Elias Jr. mentions the counterfeit letters in the commentary on Mary Barber in his recent edition of the Memoirs of Laetitia Pilkington, 2 vols. (Athens: U. of Georgia P, 1997) 2:391-92, he refrains from speculating about their authorship. Bernard Tucker, in the introduction to The Poetry of Mary Barber (?1690-1757) (Lewiston: Edwin Mellen, 1992), his abridged 
edition of Barber's Poems on Several Occasions, states that 'some evidence implicates Mary Barber in the letters' (5), but does not give this evidence.

4 Swift to Mary Pendarves (later Delany), 29 January 1736 (4:456).

5 Sarah L.C. Clapp, "The Beginnings of Subscription Publication in the Seventeenth Century', Modern Philology 19 (1931-32): 204.

6 W.A. Speck, 'Politicians, peers, and publication by subscription $1700-50$ ', Books and their Readers in Eighteenth-Century England, ed. Isabel Rivers (New York: St. Martin's, 1982) 47-48.

7 Dustin Griffin, Literary Patronage in England, 1650-1800 (Cambridge: Cambridge UP, 1996) 10.

8 Speck 48 .

9 Lonsdale 156.

10 'The Production of Belief: Contribution to an Economy of Symbolic Goods', trans. by Richard Nice, The Field of Cultural Production: Essays on Art and Literature, ed. Randal Johnson (New York: Columbia UP, 1993) 75.

11 Swift coins the term in a letter to Pope, 6 February 1730 (3:369).

12 A.C. Elias Jr.'s exhaustive research of Laetitia Pilkington (whose exclusion from the 'Triumfeminate' is puzzling, since she was much more active in the circle than Mrs. Sican appears to have been [see Ehrenpreis 3:637-38, n.5]) and Constantia Grierson has resulted in the correction of much misinformation about Mary Barber. On the authority of Mary Barber's Dictionary of National Biography entry, subsequent biographers have estimated the date of her birth as c. 1690 and erroneously reported her death as having occurred in 1757 . On the evidence of correspondence of her acquaintance, as well as parish and other records of her children, Elias estimates (I believe more accurately) Barber's date of birth at 1685, and points out that she died on 14 June 1755, not in 1757. Ehrenpreis and Lonsdale believe her husband (whose first name Elias has established is Rupert, and not Jonathan as is often reported) to have been dead by 1733 , but Elias points out that Mary Barber's obituary in the Dublin Journal 14 / 17 (June 1755) shows Rupert Barber to have survived her (see Elias, Memoirs of Laetitia Pilkington 2:391-92; Ehrenpreis 3:635-36; Lonsdale 118-19; Tucker 1-8). I am indebted to Chantel Lavoie for generously sharing some of this information with me before Elias's Memoirs came out.

13 For a fuller discussion of the delayed publication of Poems on Several Occasions, see A.C. Elias Jr., 'Editing Minor Writers: The Case of Laetitia Pilkington and Mary Barber', 1650-1850: Ideas, Aesthetics, and Inquiries in the Early Modern Era, ed. Kevin L. Cope (New York: AMS Press, 1997) 134-35 and n. 10. Although the volume was listed as in the press as early as October 1733 and the title page reads 1734, it has been known for some time that Poems on Several Occasions was published in 1735 . I have found an unindexed notice in the Gentleman's Magazine's Register of Books for May 1735 which seems to make it clear that the first edition appeared only that month: 'Those persons who have done Mrs Barber the Honour to subscribe to her Poems, are desired to send their Receipts to Mr Pond's Painter [sic] in Covent Garden, where the Books are ready to be delivered by Rupert Barber, who will attend for that Purpose, from ten in the Morning to six in the Evening, till next Midsummer Day' Gentleman's Magazine 5 (1735): 280. I think it likely that the Rupert mentioned is Mary Barber's son (then 15 or 16 years of age), rather than her husband; we know that he was with his mother in Bath, studying painting, 
for at least part of the time she was there, and surely her husband would be referred to as 'Mr. Rupert Barber.'

14 Swift to Sir Andrew Fountaine, 30 July 1733 (4:186).

1520 March 1731 (3:449-50).

16 Paul Korshin, 'Types of Eighteenth-Century Literary Patronage', Eighteenth-Century Studies 7 (1973-74): 464.

17 See note 12 .

18 See Williams 3:497 for Lady Germain's letter; The Autobiography and Correspondence of Mary Granville, Mrs. Delany, 3 vols., ed. Lady Llanover (Augusta Waddington Hall) (London, 1861) 2:481-82 for Mary Delany's letter of 22 December 1747 and 3:327-28 for her letter of 16 February 1755; 1:322 for Patrick Delany's letter of 27 February 1732.

19 Swift to Mrs. Caesar, 30 July 1733 (4:184-85).

20 Mary Barber, Preface to Poems on Several Occasions (London, 1735), xvii. All citations of Barber are from this edition. Having compared a copy of the quarto edition dated 1734 at Cornell University with McMaster University's 1735 octavo edition, I agree with Elias's assessment that the only difference between the two is 'a scattering of corrections and minor revisions' in the octavo ('Editing Minor Writers' 134).

21 See Margaret Anne Doody, 'Swift among the Women', The Yearbook of English Studies 18 (1988): 68-82 for an analysis of Barber's maternal authority and of Swift's influence on Barber's poetry.

22 Barber, Swift's dedication to Orrery iv.

23 Barber iv. See Dustin Griffin for ways in which Swift's own letter to Orrery 'is a dedication, and yet not a dedication' (Literary Patronage in England 103).

24 Miss Anne Donnellan to Swift, 10 May 1735 (4:332-33).

25 See note 2 .

26 Betty Rizzo, 'The Patron as Poet Maker: The Politics of Benefaction', Studies in Eighteenth-Century Culture 20 (1990): 241-66.

27 Carol Barash, English Women's Poetry 1649-1714: Politics, Community, and Linguistic Authority (Oxford: Clarendon P, 1996) 261.

28 Peter Quennell, Caroline of England (New York: Viking, 1940) 231.

29 See Maynard Mack, Alexander Pope: A Life, 1985 (New York: Norton, 1988) 578-79, 640 .

30 Barber, 'To Mrs. Strangeways Horner, with a Letter from my Son; wherein he desires me to accept his first Prize of Learning, conferr' $\mathrm{d}$ on him by the University of Dublin' 195-200, 61-64, 69-76. Barber's own footnote tells the reader that the 'rural Lines' are Duck's.

31 Swift to Lord Oxford, 2 August 1733 (4:187).

32 Quoted in Llanover, 1:194, n. 1.

33 3:450-51. In fairness to Gay, though, it must be noted that in the same letter he mentions recommending Barber to other potential subscribers, and that his name does appear on the list of subscribers preceding Poems on Several Occasions. 


\section{Wendy Stewart}

34 Griffin, 'Swift and Patronage', Studies in Eighteenth-Century Culture 21 (1991) 203.

35 Pierre Bourdieu, Outline of a Theory of Practice, trans. by Richard Nice (Cambridge: Cambridge UP, 1977) 5.

36 Griffin, Literary Patronage in England 121.

37 Swift to Pope, 6 March 1729 (2:315). Henrietta Howard, later Lady Suffolk, was Caroline's Bedchamber Woman, George II's mistress, and Swift's sometime friend and correspondent.

38 Jonathan Swift, the Complete Poems, ed. Pat Rogers (New Haven / London: Yale UP, 1983) 485-98, 179-88.

392 May $1730(3: 394)$. 